\section{Brazil enriches uranium}

BraziL's President José Sarney has announced that the country has now "mastered" the ultracentrifuge method of uranium enrichment, and pledged that the technology is to be used for peaceful purposes only. An enrichment plant has been established at the Resende industrial complex of the Nuclebras nuclear corporation. The director of Nuclebras, David Simon, says that in 1989 Brazil will export enriched uranium to Argentina, and that the first consignment will consist of 5 tonnes of uranium enriched to 0.85 per cent. A Sao Paulo newspaper quotes a Nuclebras official as saying that the president's announcement "fell like a bomb" on Nuclebras, since the latter's management had been "discussing" the alternative, West German, process for years "without technological barriers being overcome".

V.R

\section{Eureka cash flows}

RESEARCH and technology ministers from 20 European countries (including nonEEC members: Scandinavia, Austria, Switzerland and Turkey) met in Madrid last week to consider new projects put forward for funding by the Eureka research incentive programme. This was the fifth meeting since Eureka was set up in 1985 to increase European industrial cooperation in high-risk, new technology research.

The 58 new projects approved at the meeting represent an investment of 709 million European Currency Units (ECU), about $\mathfrak{£ 4 9 0}$ million, by member states and will bring the total number of projects supported by Eureka to 165 . Priorities agreed in Madrid include: information technology $(9$ projects, with a grant of 62 million ECU), bioengineering (11 projects, 27 million ECU), energy ( 3 projects, 25 million ECU) and new materials (2 projects, 10 million ECU).

P.C.

\section{PWR at Hinkley Point}

THE application of Britain's Central Electricity Generating Board (CEGB) for the country's second pressurized water reactor (PWR) seems certain to lead to a public inquiry. But the CEGB will not comment on the likely duration of an inquiry into the new Hinkley Point PWR, after the two-year marathon for the PWR at Sizewell B. The CEGB plans to start building the second $£ 1,500$-million PWR in 1990. It will cost $£ 200$ million less than its Sizewell predecessor.

Local authorities are objecting to Hinkley C. The CEGB proposal calls for the new nuclear reactor to be sited on four hectares of foreshore taken from a national nature reserve.

Electricity planners are considering six other potential sites for PWRs in England and Wales, as part of a programme to reduce dependence on coal-fired power stations.

\title{
US weapons laboratories an obstacle to treaty?
}

\section{Necessity for nuclear tests questioned University regents accused of "whitewash"}

\section{San Francisco}

ArE the Los Alamos and Lawrence Livermore National Laboratories standing in the way of a comprehensive test-ban treaty? A group of University of California physicists think so, and brought their case before the University of Californian Regents at their 17 September meeting in Los Angeles.

The physicists were alarmed by testimony by Roger Batzel, director of Lawrence Livermore Laboratory, to the House Armed Services Committee in September 1985. Batzel said nuclear weapons have been designed under the assumption that testing will never be banned, so continued testing is necessary to maintain their reliability.

The faculty critics oppose a design policy that requires continued nuclear testing. They feel the laboratories have too much autonomy under rather loose management by the University of California, and influence government policy to promote their own interests. These interests include an aversion to test-ban legislation that might put an end to the main livelihood of the laboratories, the development of new weapons.

The laboratories argue that they are following orders from the Department of Energy. But critics cite a potential conflict of interest because the laboratory directors also act as advisors to the government on weapons and arms control.

Lawrence Livermore theoretical physicists Hugh DeWitt and Ray Kidder charge the laboratories with misleading people about the reliability of weapon stockpiles. DeWitt and Kidder believe that current stockpiles can be relied on without nuclear testing, and many prominent physicists, including Glenn Seaborg, head of the Atomic Energy Commission for 10 years, Hans Bethe, former director of the theoretical division at Los Alamos, and Norris Bradbury, former director of Los Alamos, agree with them.

Critics claim that the laboratories have pushed weapon design parameters to their limits, in the interest of maximizing the yield-to-weight ratio. An alternative approach, says DeWitt, would be to build larger and heavier weapons that would be more certain to perform correctly. Ageing weapons could be replaced by remanufacture of identical models. The more forgiving design would ensure adequate performance without repeat nuclear tests.

John Immele, deputy associate director for nuclear design at Livermore, calls the remanufacturing idea a "pipe dream of theoreticians". Materials change, he says, and there is no way, short of a test, to be sure that remanufactured weapons will fire with the expected yield.

In addition, Immele says a comprehensive test ban would result in a drain of expertise, jeopardizing the remanufacturing process. As experienced weapons experts retired or left, new trainees who had never studied a nuclear blast would be ill-equipped to oversee the successful manufacture of nuclear weapons.

Variations of this debate have been raging for nine years, without much change in the status quo at the laboratories. Last year a faculty letter-writing campaign, instigated by Walter Kohn and Jose Fulco of University of California, Santa Barbara, persuaded university president David Gardner to order an inquiry into the faculty concerns.

The results of the inquiry by the Scientific and Academic Advisory Committee (SAAC) that oversees the laboratories, released last July, disappointed laboratory critics, who called it a "whitewash" job that found the laboratories to be "without a single blemish". But to no one's surprise, the regents accepted the SAAC report as fulfilling President Gardner's request and rejected a rebuttal prepared by the faculty group.

The scrutiny of the weapons laboratories does not end here. The university's academic senate recently set up a faculty committee to investigate the laboratories' activities and, at the request of six members of Congress, Kidder has conducted a detailed study of weapons reliability. Batzel allowed Kidder to do his analysis, but the laboratory is to submit an independent study to Congress.

In response to the laboratories' concern that a test ban would cause a drain of expertise, DeWitt and Kidder suggest that a low-threshold test ban, allowing tests of under one kiloton, would allow research and training to continue. Immele disagrees. "One kiloton is the same as zero kilotons", he says, and would allow neither understanding of the physics involved nor certification of reliability. On 19 May the House of Representatives passed a defence bill that would limit nuclear tests to less than one kiloton, if the Soviet Union agrees to do the same. A similar bill will soon be considered in the Senate.
Marcia Barinaga 